Table 1 Yield of BHMP from gas-phase ozonolysis

\begin{tabular}{|c|c|c|c|c|}
\hline Experiment* & Alkene & $\begin{array}{l}\text { Alkene } \\
\text { (mmol) }\end{array}$ & $\frac{\mathrm{O}_{3}}{\text { Alkene }}$ & $\begin{array}{r}\text { BHMP } \\
(\mathrm{mmol})\end{array}$ \\
\hline 1 & $\alpha$-Pinene & 2.65 & 2.60 & 0.28 \\
\hline 2 & & 2.65 & 1.46 & 0.07 \\
\hline 3 & & 2.65 & 0.72 & $<0.01$ \\
\hline 4 & & 2.65 & 0.85 & $0.06 \dagger$ \\
\hline 5 & $\beta$-Pinene & 2.65 & 2.34 & 0.16 \\
\hline 6 & & 2.65 & 0.84 & 0.10 \\
\hline 7 & Limonene & 2.65 & 2.73 & 0.18 \\
\hline 8 & 2-Carene & 2.65 & 2.83 & 0.20 \\
\hline 9 & Isoprene & 2.65 & 2.58 & 0.66 \\
\hline 10 & & 2.65 & 0.87 & 0.18 \\
\hline 11 & Ethene & 6.67 & 1.06 & 0.64 \\
\hline 12 & 2-Chloropropene & 4.71 & 1.81 & 0.48 \\
\hline
\end{tabular}

* All experiments except 12 were for $1 \mathrm{~h}$ at room temperature; experiment 12 was for $17 \mathrm{~h}$ at $5^{\circ} \mathrm{C}$

$\dagger 3 \mathrm{mmol} \mathrm{CH}_{2} \mathrm{O}$ were added to the reactor before ozonolysis.

Published data on ozonolysis of $\alpha$-pinene are inconsistent about the direction of cleavage of the (presumed) primary

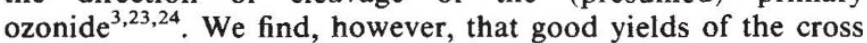
ozonide shown in equation (10) can be obtained by ozonolysis of $\alpha$-pinene in solution in the presence of $\mathrm{CH}_{2} \mathrm{O}$; this is clear evidence of cleavage as in equation (9) (to be published elsewhere). The presence of $\mathrm{CH}_{2} \mathrm{OO}$ in the $\alpha$-pinene reaction can be shown, nevertheless, even with $\mathrm{O}_{3} / \alpha$-pinene $<1$ (see Table 1 , experiment 4 , where formaldehyde is added), suggesting that the rate of ozonolysis of the rearranged carbonyl oxide is comparable with that of $\alpha$-pinene.

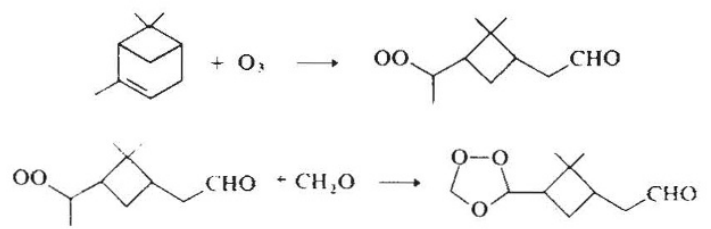

Formation of BHMP in the ozonolysis of simple alkenes, for example, ethene ${ }^{25,26}$, has been known for a long time. HMP was never detected among the ozonolysis products, probably because it is a liquid and less stable than BHMP. An ion at $m / e$ 64, corresponding to the molecular ion of HMP, has been observed in the gas-phase ozonolysis of ethene and 2-methylpropene, but the investigators were unable to explain to their satisfaction how HMP could be formed in their low-pressure system ${ }^{17}$. They did, however, recognize that the addition of water would be an important loss process for carbonyl oxides in the atmosphere ${ }^{27}$. The direct identification here of HMP and BHMP confirms these reports, but we emphasize that the reaction of water with $\mathrm{CH}_{2} \mathrm{OO}$ is a possible environmental source of the peroxide HMP at elevated ground-level $\mathrm{O}_{3}$ concentrations.

The high alkene and $\mathrm{O}_{3}$ concentrations used here probably do not affect the sequence of reactions leading to HMP from isoprene and terpenes with terminal double bonds. In view of the huge annual emission of terpenes by plants and the availability of $\mathrm{O}_{3}$ and water vapour, it is possible that considerable amounts of HMP are formed in the environment. The low concentrations of formaldehyde in the atmosphere make it less likely that much BHMP is formed. Similar considerations also apply to the question of whether HMP and BHMP are formed in smoggy urban atmospheres, where both ozone and alkenes (for example, ethene and propene) are known to be present ${ }^{1}$.

There have been several investigations of the biological activities of BHMP and HMP. BHMP has been shown to be a mutagen in experiments on root meristem cells (Vicia faba $)^{12}$, as well as in Drosophila ${ }^{28}$ and Neurospora ${ }^{29}$, and it has cytostatic activity in mouse tumour cells ${ }^{30}$. Several enzymes, especially those with $-\mathrm{SH}$ groups, are inhibited by $\mathrm{BHMP}^{13,31}$; it may be significant that horseradish peroxidase is irreversibly inhibited ${ }^{14}$.
Two studies on BHMP have indicated that the effects observed resulted from a product, presumably HMP, formed by hydrolysis of BHMP in the test system ${ }^{12,13}$; the possibility that these were the results of further hydrolysis of $\mathrm{H}_{2} \mathrm{O}_{2}$ could be eliminated ${ }^{29,32}$. Despite the implications of these results, there appear to have been no studies of the response of whole plants or mammals to HMP and BHMP. Both of these substances are rather unstable under physiological conditions ${ }^{33}$, and it is unknown whether they can enter intact plants. It is important that attempts be made to detect HMP in the environment and to determine whether its lifetime is long enough for it to influence vegetation.

Received 21 March; accepted 10 June 1985

1. Pitts, J. N. Jr \& Finlayson, B. J. Angew. Chem. 87, 18-33 (1975).

2. Went, F. W. Proc. natn. Acad. Sci. U.S.A. 46, 212-221 (1960).

3. Graedel, T. E. Rev. geophys. Space Phys. 17, 937-947 (1979)

4. Warmbt, W. Z. Met. 29, 24-31 (1979)

5. Penkett, S. A. Nature 311, 14-15 (1984)

6. Frank, H. Nachr. Chem. Tech. 32, 298-305 (1984).

Kohlmaier, G. H., Bröhl, H. \& Siré E. O. Allg. Forst Jagdztg. 154, 170-174 (1983).

8. Schöpfer, W. \& Hradetzky, J. Forstwiss. Zentbl. 103, 231-246 (1984).

9. Prinz, B., Krause, G. H. M. \& Stratmann, H. Landesanstalt für Immissionsschutz des Landes Nordrhein-Westfalen, Essen, Bericht 28 (1982).

10. Rasmussen, R. A. J. Air. Poll. Contr. Ass, 22, 537-543 (1972)

11. Zimmerman, P. R., Chatfield, R. B., Fishman, J., Crutzen, P. J. \& Hanst, P. L. Geophys. Res. Lett. 5, 679-682 (1978)

12. Keusch, F. Ber. schweiz. bot. Ges. 81, 180-272 (1971).

13. Marklund, S. Biochim biophys. Acta 258, 9-16 (1972)

14. Marklund, S. Archs Biochem. Biophys. 154, 614-622 (1973).

15. Rieche, A. \& Meister, R. Chem. Ber. 68, 1468-1472 (1935)

16. Rieche, A. \& Meister, R. Chem. Ber. 66, 718-727 (1933).

17. Martinez, R. I., Herron, J. T. \& Huie, R. E. J. Am. chem. Soc. 103, 3807-3820 (1981).

18. Bailey, P. S. Ozonation in Organic Chemistry Vol. 1 (Academic, New York, 1982).

19. Cox, R. A. \& Penkett, S. A. JCS Faraday Trans. 1 68, 1735-1753 (1972).

20. Su, F., Calvert, J. G. \& Shaw, J. H. J. phys. Chem. 84, 239-246 (1980),

21. Story, P. R. \& Burgess, J. R. J.. Am. chem. Soc. 89, 5726-5727 (1967).

22. Wadt, W. R. \& Goddard III, W. A. J. Am. chem. Soc. 97, 3004-3021 (1975).

23. Lloyd, A. C., Atkinson, R., Lurmann, F. W. \& Nitta, B. Atmos. Envir. 17, 1931-1950 (1983).

24. Arora, P. K. \& Vohra, K. G. Chem. Phys. Lett. 96, 161-166 (1983).

25. Briner, E. \& Schnorf, P. Helv. chim. Acta 12, 154-181 (1929)

26. Briner, E. \& Meier, R. Helv. chim. Acta 12, 529-553 (1929).

27. Herron, J. T., Martinez, R. I. \& Huie, R. E. Int. J. chem. Kin. 14, 201-224 (1982)

28. Sobels, F. H. Nature 177, 979-982 (1956).

29. Dickey, F. H., Cleland, G. H. \& Lotz, C. Proc, natn. Acad. Sci. U.S.A. 35, 581-586 (1949).

30. Weitzel, G., Buddecke, E. \& Schneider, F. Hoppe-Seylers Z. physiol. Chem. 323, 211-235 (1961).

31. Weitzel, G., Buddecke, E., Schneider, F. \& Pfeil, H. Hoppe-Seylers Z. physiol. Chem. 325, $65-90$ (1961).

2. Loveless, A. Nature 167, 338-342 (1951).

33. Marklund, S. Acta chem. Scand: 25, 3517-3531 (1971)

\section{The effect of climate on long-term changes in the crustacean zooplankton biomass of Lake Windermere, UK}

\section{G. George* \& G. P. Harris $\dagger$}

* Freshwater Biological Association, The Ferry House,

Ambleside, Cumbria LA22 0LP, UK

† CSIRO Division of Fisheries Research, Hobart,

Tasmania 7001, Australia

Fish predation is increasingly being viewed as one of the most important factors influencing the development of zooplankton populations in lakes ${ }^{1-3}$. Marine zooplankton populations, on the other hand, are thought to be influenced primarily by the climate ${ }^{4,5}$. We show here that year-to-year fluctuations in the biomass of crustacean zooplankton in Lake Windermere, in the United Kingdom, are strongly correlated with variations in water temperature, but poorly correlated with the abundance of the dominant planktivorous fish. This represents the first conclusive evidence of climatologically induced variability in a freshwater planktonic ecosystem. The links between climate and fisheries have recently been summarized by Cushing ${ }^{6}$, who suggests that climatic events regulate fish production through the matching or mismatching of their spawning with the period of available food. Our observations, reported here, suggest that year-to-year fluctuations in the biomass of crustacean zooplankton in Windermere are similarly influenced by the matching or mismatching of seasonal events in the zooplankton with the availability of algal food. 
Months

\section{$J F M A, M J J A, S, O N, D$}
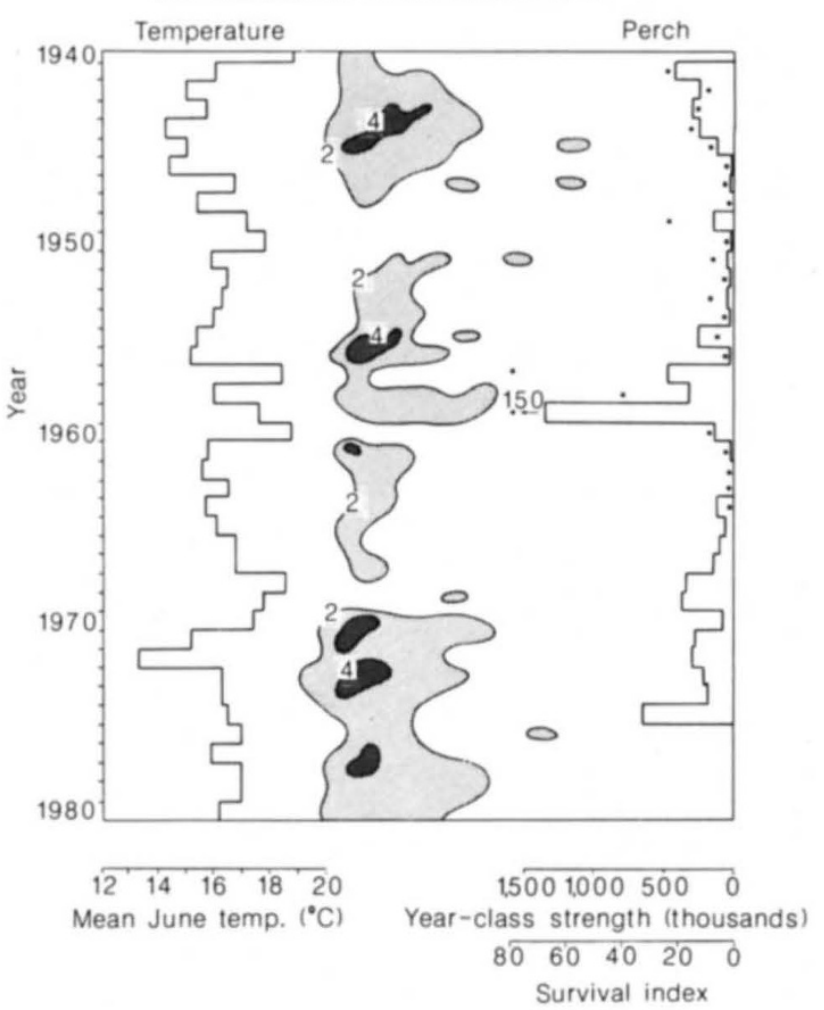

Fig. 1 The contour diagram shows the annual and seasonal variations in the biomass of crustacean zooplankton in the north basin of Windermere between 1940 and 1980 . Biomass was estimated by a simple volumetric technique ${ }^{23}$; the values shown are dry weights $\mathrm{m}^{-2}$. The left-hand histogram shows the year-to-year variations in mean June temperature, and is based on weekly measurements at a central station in the north basin. All temperature measurements were taken in the top $5 \mathrm{~m}$ with a combined temperature and oxygen electrode (Mackereth). The right-hand histogram shows year-toyear variations in the year-class strength of perch between 1940 and $1976^{10}$ and includes estimates of a survival index for the years 1941-1964 ${ }^{9}$. In 1976 the perch populations in Windermere were dramatically depleted by fungal disease ${ }^{15}$.

Windermere is the largest lake in the English Lake District $\left(54^{\circ} 22^{\prime} \mathrm{N}, 2^{\circ} 56^{\prime} \mathrm{W}\right)$; it is divided into two distinct basins by an island and a region of shallows less than $5 \mathrm{~m}$ deep. The north basin is $8.05 \mathrm{~km}^{2}$ in area and $64 \mathrm{~m}$ deep; the more productive south basin covers $16.78 \mathrm{~km}^{2}$ and is $42 \mathrm{~m}$ deep. Long-term changes in the chemistry of Lake Windermere have been summarized by Sutcliffe et al. $^{7}$, and Lund ${ }^{8}$ has published several accounts of the indigenous phytoplankton. The numbers and biomass of perch (Perca fluviatilis L.) in Windermere have been recorded and analysed every year since $1941^{9,10}$, and the food preferences of the young perch have also been studied periodically $^{11-13}$. The crustacean zooplankton samples analysed here were collected from the north basin at fortnightly intervals between 1940 and 1980. All the samples were collected at the same mid-lake station by hauling a net vertically through the water column from a depth of $40 \mathrm{~m}$. The conical net used had a mouth area of $700 \mathrm{~cm}^{2}$, a mesh size of $240 \mu \mathrm{m}$ and efficiently captured all crustacea larger than first- or second-stage copedites. Occasional qualitative checks showed that the crustacean zooplankton populations in the north basin have changed little in the last 40 years. More detailed studies of samples collected in the last 10 years showed that, while the absolute abundance of the various species changed from year to year, there was no major shift in species dominance. The summer zooplankton crops are dominated by the cladoceran Daphnia hyalina var. galeata Sars and the cyclopoid copepods Cyclops strenuus abyssorum Sars and Cyclops leuckarti (Claus). Appreciable num-

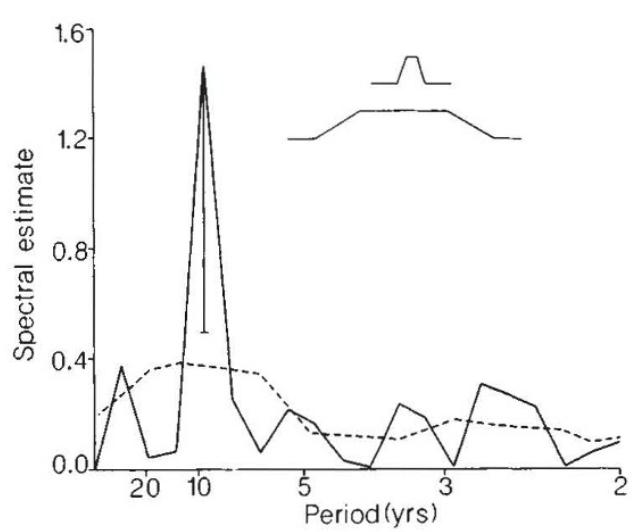

Fig. 2 High-resolution (-) and low-resolution (- - ) spectra for the 40-yr record of mean June temperature. The spectra were obtained by smoothing the raw spectra with the trapezium frequency window. The inset shows the bandwidths and smoothing window shapes for the two spectra. The main peak in the highresolution spectrum is judged significant as its one-sided $95 \%$ confidence interval $(P<0.05)$ does not include the corresponding value in the low-resolution spectrum.

bers of the calanoid copepod Diaptomus gracilis Sars are present throughout the year, and two large cladoceran species Leptodora kindti (Focke) and Bythotrephes longimanus Leydig, appear for short periods in summer.

The contour diagram in Fig. 1 shows the seasonal and annual changes in crustacean zooplankton biomass that have occurred in the north basin between 1940 and 1980 . It seems likely that the biomass of crustacean zooplankton has increased as a result of nutrient enrichment in recent years ${ }^{7}$, but the most obvious pattern is a quasi-cyclical variation with a period of about 10 years. Direct counts on a portion of this record show that the fluctuations in biomass principally reflect variations in the numbers of $D$. hyalina, the dominant herbivore. In Fig. 1 these fluctuations are compared with year-to-year fluctuations in mean June temperature and the recruitment and survival of perch. A. E. Irish (personal communication) has analysed the historical temperature records for Windermere ${ }^{14}$ and found that June is the only month in which a significant long-term autocorrelation is apparent. More detailed analyses of the Windermere temperature profiles show that these temperature variations are directly related to the timing of thermal stratification. The yearclass strength records in Fig. 1 are a relative measure of the numbers of perch hatching each year and were obtained by trapping 2-yr-old fish. The assumptions inherent in these calculations have been discussed by Le Cren et al. ${ }^{9}$, who emphasize the relative nature of these estimates. A close examination of Fig. 1 suggests that the changes in crustacean zooplankton biomass are inversely related to mean June temperature, but bear very little relationship to either the year-class strength or the survival of perch. For example, the zooplankton fared poorly in 1950 and 1963 when there were few young perch in the lake, and reached quite high numbers in 1959 when perch were exceptionally abundant. The catastrophic incidence of perch disease in $1976^{15}$ also appears to have had little effect on crustacean zooplankton biomass. The very strong year-class of perch produced in 1959 may, however, have had some long-term effects, but the impact of older fish is difficult to assess as they do not feed extensively on zooplankton ${ }^{12,13}$.

The overall interrelationships between crustacean zooplankton biomass, water temperature and perch recruitment are summarized by a series of multiple regressions in Table 1 . Variations in the year-class strength of perch account for only $6.5 \%$ of the variation in crustacean zooplankton biomass, whereas variations in June water temperature account for almost $35 \%$ of the year-toyear variations in biomass. Such minor year-to-year variations in water temperature can have little direct effect on the survival and reproductive potential of the crustacean zooplankton; they are significant only insofar as they act as a surrogate for more 


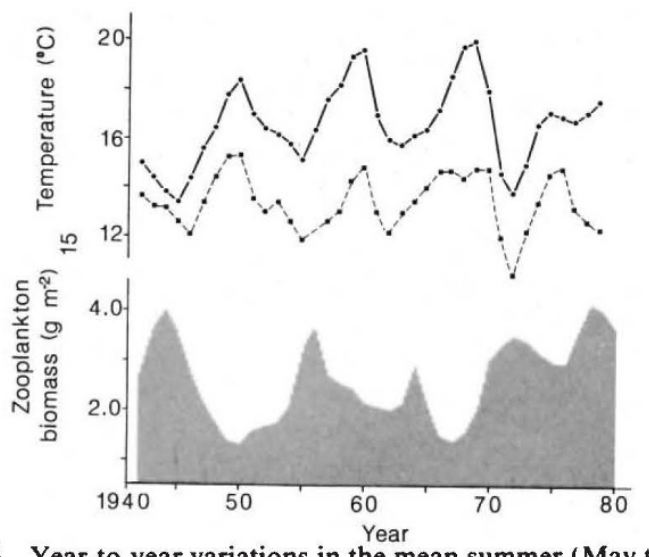

Fig. 3 Year-to-year variations in the mean summer (May to September) biomass of crustacean zooplankton in the north basin of Windermere, compared with year-to-year variations in mean June air ( $\square$ ) and water ( ) temperature. The zooplankton biomass and water temperature data are taken from Fig. 1, and the air temperatures were obtained from a local meteorological stations. All the data were smoothed with a three-point-centred moving average with weights $0.25,0.5$ and 0.25 .

fundamental weather-related factors such as wind-induced mixing.

Recently, several attempts have been made to resolve historically short-term (decades) periodicities in physical and biological data ${ }^{6}$. To assess the statistical significance of our temperature cycle, we have analysed our 40-year record using techniques of spectral analysis. Figure 2 shows the high-resolution and lowresolution spectra obtained from the 40-year record of mean June temperature. The peak at $9.8 \mathrm{yr}$ in the high-resolution spectrum was tested by the bandpass filtering technique suggested by Hays et al. ${ }^{16}$ and judged significant at $P<0.05$. The relationship between crustacean zooplankton biomass and this '10-year' temperature cycle is highlighted graphically in Fig. 3. This figure compares smoothed estimates of mean summer biomass with similar smoothed estimates of June air and water temperatures. There is a clear pattern of low zooplankton biomass in the summers following warm Junes, and high zooplankton biomass in the summers following cool Junes. The pattern is most pronounced for the temperature cycles recorded between 1940 and 1970 . In the early 1970s, the weather pattern over northern Europe changed abruptly as northerly winds weakened and westerlies became dominant ${ }^{17}$. The less extreme biomass fluctuations recorded in Windermere over recent years may, in part, reflect this stabilizing influence. It is interesting that the water temperatures in Fig. 2 follow a more pronounced cycle than the air temperatures. This suggests that the onset of thermal stratification is strongly influenced by wind-induced mixing as well as by surface irradiance.

There seems little doubt that the quasi-cyclical events observed in Lake Windermere reflect a much wider pattern of climatic

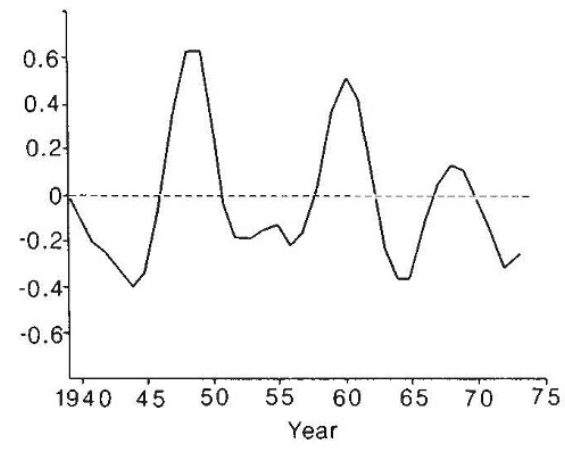

Fig. 4 The quasi-cyclical element of means of sea-surface temperature recorded in Marsden square $145 \mathrm{D}\left(45-50^{\circ} \mathrm{N}, 10-50^{\circ} \mathrm{W}\right)$ for the period $1940-1973^{20}$. The plot was derived from the original data by the application, as a filter, of the second eigenvector of the matrix of serial correlations with a maximum lag of 7 years ${ }^{5}$.

variation. An approximately 10 -yr periodicity in sea-surface temperature has been reported for several areas of the North Atlantic by Maximov et al. ${ }^{18}$ and for the English Channel by Southward et al. ${ }^{19}$. More recently, Colebrook and Taylor ${ }^{20}$ have demonstrated a pronounced temperature cycle for Marsden square 145D (southern Celtic Sea and the northern Bay of Biscay). Figure 4 shows the annual mean anomaly of sea-surface temperature taken from their paper $^{20}$ for the period 1940-1973. The general similarities between the pattern of change in Windermere and the western sea approaches are fairly obvious. Colebrook and Taylor believe that this cyclical pattern is determined primarily by direct heat exchange but is again mediated by the meridional component of the surface winds.

Clearly, more information is needed to fully document the links between climate and zooplankton production in Windermere. Cushing ${ }^{6}$ has hypothesized that fish recruitment is strongly influenced by the matching or mismatching of the period of larval production with the period of available larval food. It seems likely that a comparable match/mismatch process controls the crustacean herbivore cycle in Windermere. Our preliminary observations certainly point to the importance of physical conditions in early summer, and suggest that these conditions influence the timing of biological events in the lake. Phytoplankton succession is known to be strongly influenced by weather-related mixing episodes ${ }^{21}$. Experimental studies in other lake systems ${ }^{22}$ also demonstrate that the availability of algal food influences the subsequent development of the crustacean plankton.

In Windermere, stratification is followed by the sedimentation of the spring diatom crop and the growth of a variety of nanoplankton. These small, rapidly growing species are an important source of food for filter-feeding crustacea who are less able to feed on the larger, slow-growing species that occur later in summer. The long-term nanoplankton records for Windermere

Table 1 Stepwise multiple regression of mean crustacean zooplankton biomass on mean June temperature $(T)$ and on the year-class strength of perch $(p)$

\begin{tabular}{lccc}
\hline & d.f. & Sum of squares & Variance ratio \\
Regression on $p$ alone & 1 & 0.023 & 0.023 \\
Further inclusion of $T$ in regression & 1 & 0.532 & 0.532 \\
Regression on both $p$ and $T$ & 2 & 0.554 & 0.277 \\
Regression on $T$ alone & 1 & 0.452 & 0.452 \\
Further inclusion of $p$ in regression & 1 & 0.102 & 0.102 \\
Regression on both $p$ and $T$ & 2 & 0.554 & 0.277 \\
Residual & 32 & 1.005 & 0.031 \\
Total & 34 & 1.559 & 0.046 \\
\hline
\end{tabular}

d.f., Degrees of freedom; NS, not significant. 
have not yet been analysed in detail (J.W.G. Lund, personal communication). Preliminary studies nevertheless suggest that the critical reproductive period for the crustacean zooplankton is more likely to coincide with the period of maximum food availability in 'cool' rather than 'warm' Junes. In warm Junes the preferred food species tend to appear earlier and may be in decline by the time the Daphnia start to reproduce rapidly.

The samples analysed in this paper have been collected, regularly, for a period of $>40 \mathrm{yr}$. The authors would like to acknowledge their debt to all FBA staff who have been involved with this sampling programme. We thank $A$. H. Taylor and $R$. T. Clarke for critical comments on the manuscript, and M. A. Hurley and G. Tunnicliffe-Wilson for statistical advice.

Received 15 April; accepted 23 May 1985.

1. Brooks, J. L. \& Dodson, S. I. Science 150, 28-35 (1965)

2. Wells, L. Limnol, Oceanogr. 15, 556-565 (1970).

3. Hall, D. J., Threlkeld, S. T., Burns, C. W. \& Crawley, P. H. A. Rev. Ecol Syst. 7, 177-208 (1976)

4. Colebrook, J. M. Rapp. P.-v. Réun. Cons. perm. int. Explor. Mer 172, 390-396 (1978).

5. Colebrook, J. M. Oceanol. acta 1, 9-23 (1978).

6. Cushing D. H. Climate and Fisheries (Academic, London, 1982)

7. Sutcliffe, D. W. et al. Freshwat. Biol. 12, 451-506 (1982).

8. Lund, J. W. G. J. Ecol. 38, 1-35 (1950); Verh. int. Verein. theor, angew. Limnol. 14, 147-154 (1961)

9. Le Cren, E. D., Kipling, C. \& McCormack, J. C. J. Anim. Ecol. 46, 281-307 (1977)

10. Craig, J. F., Kipling, C., Le Cren, E. D. \& McCormack, J. C. J. Anim. Ecol 48, 315-325 (1979)

11. McCormack, J. C. J. Anim. Ecol. 39, 255-267 (1970).

12. Craig, J. F. Freshwat. Biol. 8, 59-68 (1978)

13. Guma'a, S. A. Freshwat. Biol 8, 177-187 (1978)

14. Kipling, C. \& Roscoe, M. E. Occ. Publs Freshwat. Biol. Ass. 2 (1977).

15. Bucke, D., Cawley, G. D., Craig, J. F., Pickering, A. D. \& Willoughby, L. G. J. Fish Dis. 2, 297-311 (1979).

16. Hays, J. D., Imbrie, I. \& Shackleton, N. J. Science 194, 1121-1132 (1976).

17. Dickson, R. R., Lamb, H. H., Malmberg, S.-A. \& Colebrook, J. M. Nature 256, 479-482 (1975).

18. Maximov, I V Sarukhanyan, E I \& Smirnov, N P Rapp. P.v. Réun. Cons perm int Explor. Mer 162, 159-166 (1972)

19. Southward, A. J., Butler, E. I. \& Pennycuick, L. Nature 253, 714-717 (1975)

20. Colebrook, J. M. \& Taylor, A. H. Deep Sea Res. 26A, 825-850 (1979).

21. Reynolds, C. S. The Ecology of Freshwater Phytoplankton (Cambridge University Press, 1984).

22. Thompson, J. M., Ferguson, A. J. D. \& Reynolds, C. S. J. Plankton Res. 4, 545-560 (1982). 23. George, D. G. \& White. N. J. J. Plankton Res. 7, $411-414$ (1985).

\section{Taxonomic affinities of the immature hominid crania from Hadar and Taung}

\section{Todd R. Olson}

City University of New York Medical School,

Convent Avenue at 138th Street,

New York, New York 10031, USA

The description' of the AL 333-105 cranium from the East African Pliocene provides a new opportunity to re-examine the sugges$\operatorname{tion}^{2-4}$ that the Taung child may be a robust rather than a gracile form of early hominid. Comparisons of these two crania with the skulls of living and fossil hominoids indicate that AL 333-105 possesses autapomorphic features associated with paranthropine masticatory hypertrophy, and provide additional evidence for the existence of this lineage in the Hadar Formation. Here, I report a study of the facial morphology of the Taung specimen which, together with recent observations on its dentition ${ }^{5}$, provides strong evidence against the allocation of the Taung child to the Paranthropus clade. The identity of the specimen is recognized as being in the Homo lineage.

The comparison of 71 crania of Gorilla, 85 of Pan troglodytes, 67 of Pan paniscus, 40 of Pongo and 164 of Homo sapiens demonstrates that nasal bone outline and the relationships of the frontal, nasal and maxillary bones are highly consistent within and between these taxa. Typically, in great apes of both sexes and all age groups, nasion and glabella are closely approximated on the supraorbital torus (Fig. 1). The nasal bones are widest immediately superior to the piriform aperture and they converge superiorly. The relatively large maxillary processes of the frontal bones project inferiorly beside the nasal bones,

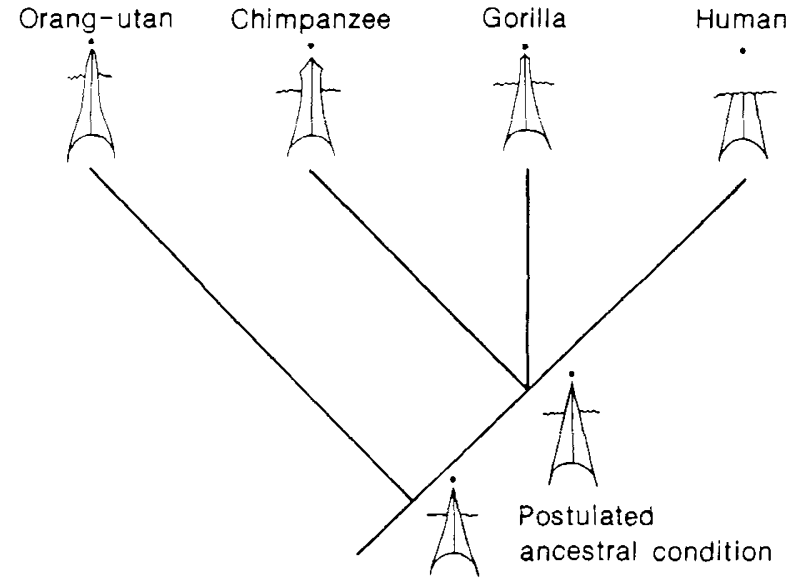

Fig. 1 Cladogram of extant hominoid taxa, illustrating the nasal bones and superior margin of piriform aperture in norma frontalis. Figures (to scale) indicate the differences between the nasal outlines and the relative positions of nasion to glabella $(\bullet)$.

placing the frontomaxillary sutures in a roughly transverse plane below the level of nasion.

The significance and primitive nature of this pattern in the great apes are further indicated by: (1) its presence in the orang-utan where the inter-orbital region is derived; (2) its existence in the Miocene ape Sivapithecus ${ }^{6}$; and (3) the minimal variation found between infant and adult specimens. The third observation is particularly strong evidence that great-ape nasal morphology is symplesiomorphic.

In contrast, the morphology of the nasal region in $H$. sapiens is derived in the reduction or absence of the maxillary processes of the frontal bone as seen in a frontal view, and in the location of nasion relative to glabella (Fig. 1). In $H$. sapiens, the frontonasal and frontomaxillary sutures are linear and continuous below an anteriorly projecting supraorbital torus, and nasion is removed from its primitive association with the supraorbital torus and glabella (Fig. 1).

The ontogenetic evidence for a consistent association of these features in $H$. sapiens is compelling. Fetal human crania exhibit the adult condition even in the absence of a supraorbital torus ${ }^{7}$. The data collected in this study from an ontogenetic series of $H$. sapiens crania ${ }^{8}$ agree with the developmental data from other hominoid taxa. Thus, nasal morphology is useful in determining the phylogenetic affinities of both adult and immature fossil crania.

The taxonomic relevance of nasal morphology to early hominid systematics is further increased by the existence in Paranthropus of a third derived pattern (Fig. $2 a-d$ ). In Paranthropus, the lateral margins of the nasal bones are derived from the primitive hominoid pattern in the way they diverge superiorly. However, the primitive relationships between: (1) nasion and glabella; and (2) the frontonasal and frontomaxillary sutures are retained. Nasion and glabella are closely approximated well above the points where the frontomaxillary sutures meet the nasal bones, and the nasomaxillary sutures are either parallel or divergent superiorly. The frontal profile of paranthropine nasal bones is described here as a 'keystone' pattern.

Loading of the anterior dentition during occlusion has been shown ${ }^{9}$ to generate intense forces in the face that are transmitted through the frontal processes of the maxillae to the supraorbital torus, where they are dissipated in the cranial vault. In hominoids with a primitive triangular nasal profile (Fig. 1), the frontal processes of the maxillae act as simple pillars that transmit force directly to the beam-like supraorbital torus. The derived keystone condition in Paranthropus is an adaptation that more evenly distributes anterior occlusal forces through the supraorbital torus to the cranial vault.

A supported arch with its central keystone functions to distribute overlying weight evenly to laterally located pillars. The 